\title{
Introduction of Ophiolitic Complex Rock Series in the 1:100,000 Sheet of Mianrahan (West of Iran)
}

\author{
Hamideh Farahmand, Mohammad Ali Arian* \\ Department of Geology, Faculty of Science, North Tehran Branch, Islamic Azad University, Tehran, Iran \\ Email: ^farahmand_hamideh@yahoo.com
}

How to cite this paper: Farahmand, H. and Arian, M.A. (2016) Introduction of Ophiolitic Complex Rock Series in the 1:100,000 Sheet of Mianrahan (West of Iran). Open Journal of Marine Science, 6, 538-546. http://dx.doi.org/10.4236/ojms.2016.64043

Received: August 30, 2016

Accepted: October 28, 2016

Published: October 31, 2016

Copyright $\odot 2016$ by authors and Scientific Research Publishing Inc. This work is licensed under the Creative Commons Attribution International License (CC BY 4.0). http://creativecommons.org/licenses/by/4.0/

\begin{abstract}
The Mianrahan's ophiolitic complex out crops in the northeast of Kermanshah and along with the Zagros thrust zone. In Mianrahan sheet, these ophiolites are located along the NW-SE and parallel to the Zagros Thrust in the ground. The rocks of this ophiolite complex consist of peridotite, serpentinites, gabbro, dolerite dykes, basaltic lavas associated with marine sediments containing the cretaceous limestones, siliceous limestones and radiolarites. Stratification of this ophiolitic complex is similar to lithological facies sequence of the oceanic crust. However, in some parts, it could be seen as scattered and melanged in the ground. Petrographic study of Mianrahan's ophiolitic complex started with the ultramafic sequence and followed by sedimentary rocks.
\end{abstract}

\section{Keywords}

Mianrahan, Kermanshah, Zagros Thrust, Ophiolitic Complex

\section{Introduction}

In Iran country, the Zagros suture zone extends from Iranian-Turkish border in the North West of country, to the north of the Hormuz Strait in southern Iran and Northern Persian Gulf, and is an important part of the Alpine-Himalayan orogenic belt that includes the ophiolites investigated in this study. Mianrahan's ophiolite located in tectonic-structural zone of the Zagros Thrust in the West of Iran, the northern part of the Main Zagros Thrust and is considered as a part of ophiolite sequences in the Zagros suture zone [1] (Figure 1). The complex is a part of the $3000 \mathrm{~km}$ strip starts from Syria and after passing through southern Turkey and Zagros goes to Oman. Zagros ophiolites are exposed in along and in the immediate northeast of the Zagros Main Thrust in two separate parts; the one in Kermanshah province and the other in Fars province in 

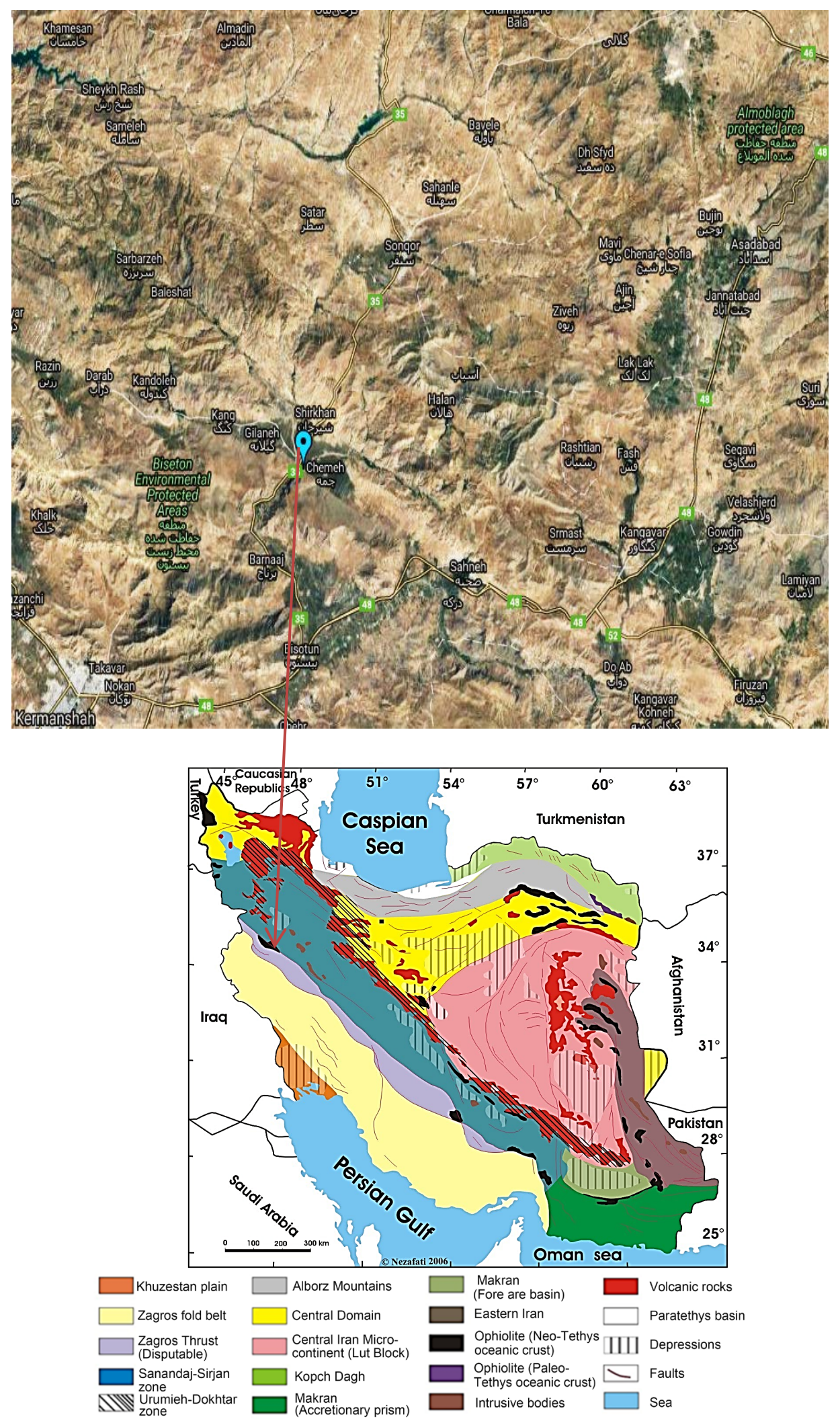

Figure 1. Main structural-tectonic units of Iran (Stocklin, 1968) and geographical location of the study area. 
Neyriz. In terms of composition and structure, the two ophiolitic complexes of Kermanshah and Neyriz in Fars province have a great similarity with the ophiolite-radiolarite complex of Oman, known as the Samailophiolite, and ophiolites of the margin of Saudi Arabiam [2]. This article tries to investigate the sequence of Mianrahan'sophiolitic complex based on the field geological and lithological surveys. In the geological map, Mianrahan is located at a scale of 1:100,000 and between $47^{\circ}$ to $47^{\circ} 30^{\prime}$ east longitude and $34^{\circ} 30^{\prime}$ to $35^{\circ}$ north latitude [3] (Figure 2).

Mianrahan is an ophiolitic complex that for the first time was introduced by Brown (1989) and subsequently described by other researchers [4]. To do this research, 120 rock samples were selected from the ophiolite complex for petrographic studies. In the following, the ophiolite rocks complex and their arrangement will be discussed.

\section{Discussion}

In the geological map of Mianrahan, there are a series of rocks related to an ophiolitic complex. This ophiolitic complex is related to the remanets of Neotethys oceanic crust. The Neotethysocean was locate between the Arabian Shield and Iran's block and closed in the Upper Cretaceous. In Mianrahan area which the Zagros Thrust is also present, a series of rocks of the ophiolitic complex from down to up include: 1) Peridotitic rocks, 2) Gabbros, 3) Doleritic dykes, 4) Basaltic lavas and 5) Limestones and radiolarites. This ophiolitic complex contains extensive area of the map and has a relatively good order but in some parts, the activity of Zagros thrust is intense and the complex could be circles, observed as mixed form in the ground that called colored melange (Figure 4(d)). Here, each of these constituent units of ophiolitic complex would be described from old to new. In ophiolitic complex rocks, a variety of peridotite including harzburgite and lherzolite could be seen that in terms of volume, harzburgites present with the maximum volume and composition close to dunite and lherzolite with the average to low volume and composition close to harzburgite. Many peridotites also serpentinized which known as serpentinite and will be described. Nomenclature of the ultramafic igneous rocks of ophiolitic complex was conducted based on the result of modal analysis (Table 1), and according to quantitative mineralogical classification of ultramafic rocks by [5] (Figure 3).

Table 1. Results of modal analysis of the rocks of Mianrahan's ophiolitic complex.

\begin{tabular}{cccccc}
\hline Minerals & $\begin{array}{c}\text { Harzburgite } \\
\text { sample 34 }\end{array}$ & $\begin{array}{c}\text { Harzburgite } \\
\text { sample 38 }\end{array}$ & $\begin{array}{c}\text { Lherzolite } \\
\text { sample 66 }\end{array}$ & $\begin{array}{c}\text { Lherzolite } \\
\text { sample 68 }\end{array}$ & $\begin{array}{c}\text { Harzburgite } \\
\text { sample 58 }\end{array}$ \\
\hline Olivine & 60 & 57 & 51 & 58 & 60 \\
Orthopyroxene & 33 & 13 & 14 & 18 & 5 \\
Augite & - & 5 & 7 & 5 & 7 \\
Opaque mineral & 1 & 3 & 5 & 1 & - \\
Serpentine & 5 & 22 & 23 & - & 18 \\
Calcite & 1 & - & - & - & 1 \\
\hline
\end{tabular}




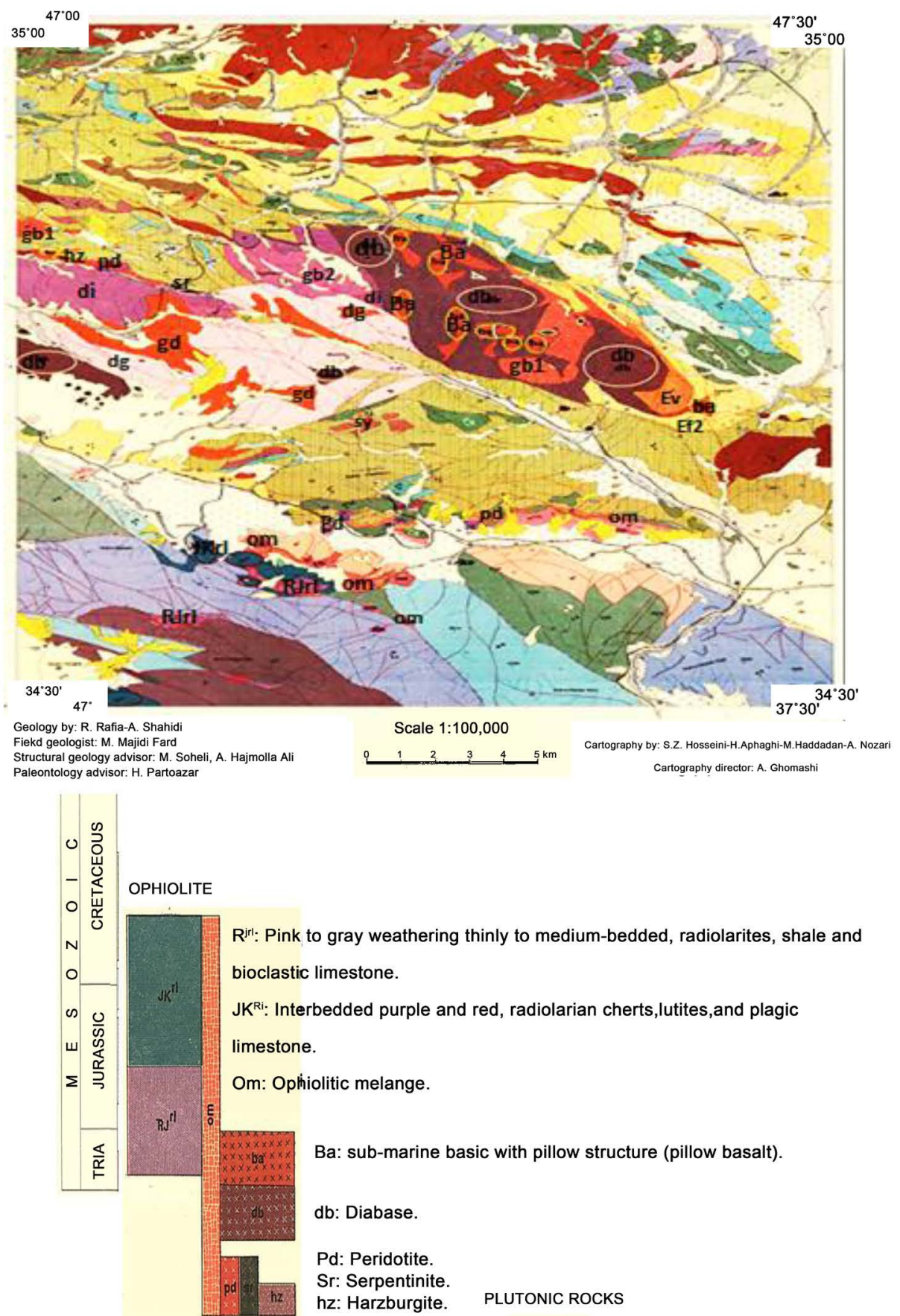

\begin{tabular}{|l|l}
\hline & Gb2: Gabbro \\
\hline & gb1: Gabbro \\
\hline $\mathrm{d}$ & di: Diorite \\
\hline $\mathrm{dg}$ & dg: Diorite gabbro \\
\hline & gd: Gabbro diorite \\
\hline & sy: syenite \\
\hline
\end{tabular}

Figure 2. Geological map of the study area (Rafia \& Shahidi, 1999) ophiolitic out crops show with circles. 


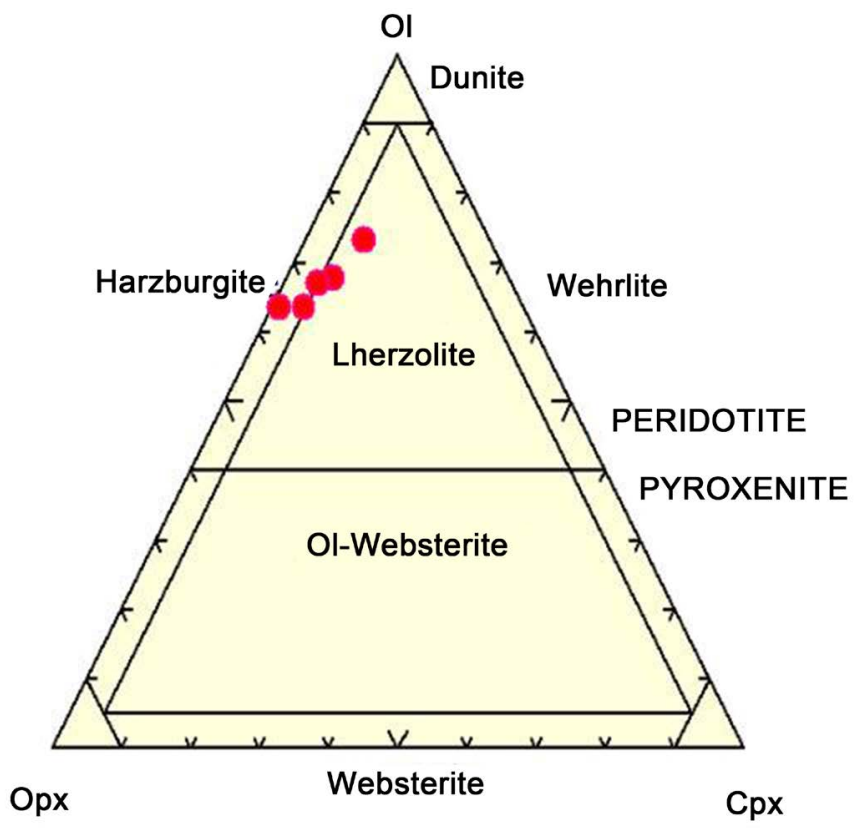

Figure 3. The quantitative mineralogical classification of ultramafic rocks (Streckeisen, 1979). Some ultramafic rocks of ophiolitic complex were positioned and named on this diagram according to the result of modal analysis.
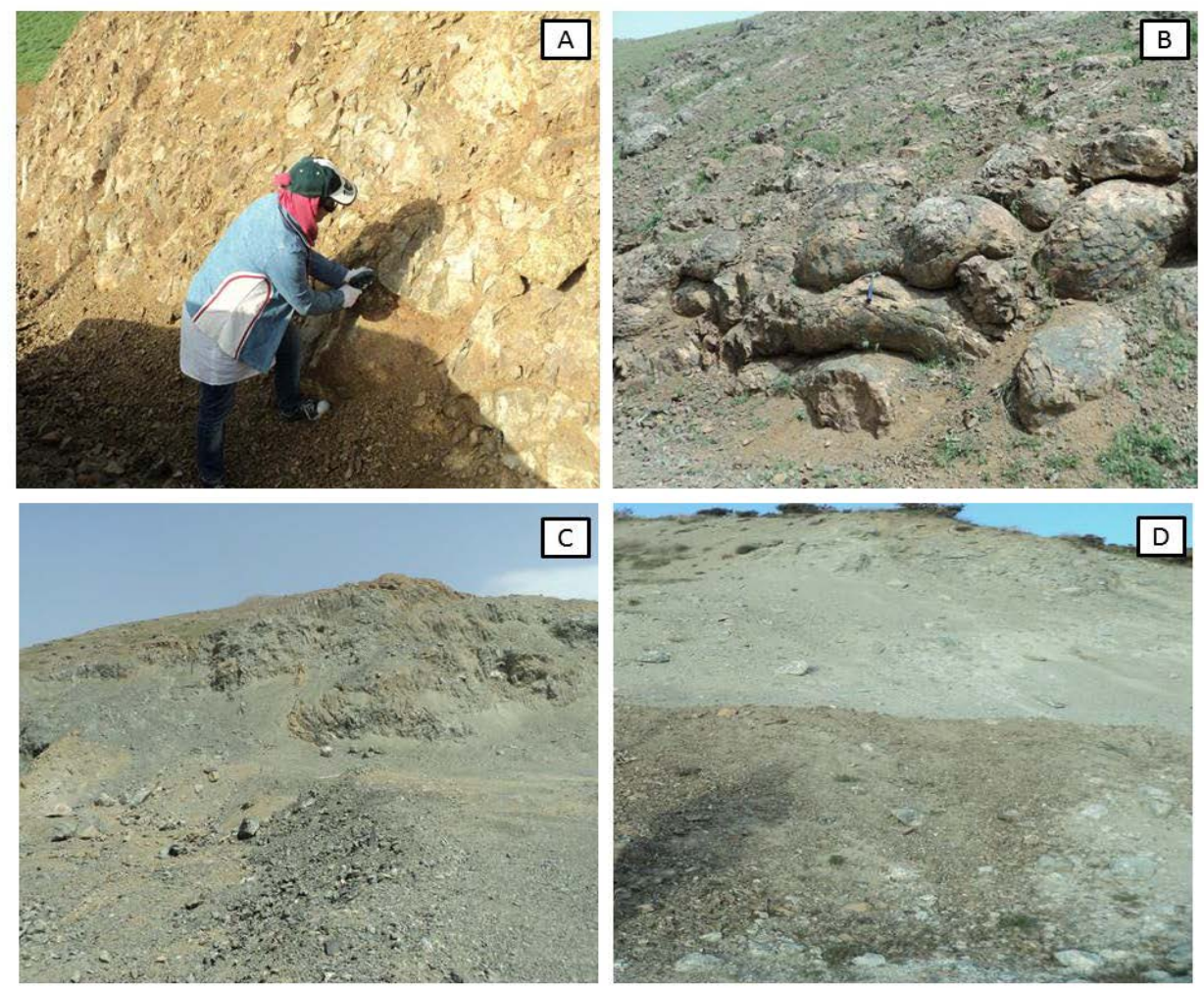

Figure 4. The rocks outcrop of Mianrahan's ophiolite sequence. (a) A view of the diabase dykes, (b) an outcrop of pillow lavas, (c) a view of the region's peridotite, (d) an outcrop of the ophiolitic melange. 
Peridotites are the lowest part of ophiolitic complex and have very low out crops in the study area [6]. In most parts, the Eocene or Upper Cretaceous sediments have been thrusted on this complex. A view of peridotites located in the northern Aliabad village and the northeast of Cheshmeh Gholamvais (Figure 4(c)) shows that the peridotites are juxtaposed with the adjacent sediments by faults. Harzburgites made up of olivine, orthopyroxene and some augite. These rocks have the massive and granular structure and their color is dark gray to grayish green to black. Bronzite and serpentine are observed on the rock surface. These rocks have the medium to coarse-grained pophyritic texture and the mechanical twinning would be observed in orthopyroxene crystals.

Olivine comprises 51 to 60 percent of the rock volume and is xenomorph and has the length up to $7 \mathrm{~mm}$ and serpentine is its alteration product. Serpentine has filled the mineral's fractures. In a way that 5 to 27 percent of the rock is made up of these secondary serpentines. Enstatite comprises 5 to 33 percent of the rock and is sub-automorph and has up to $4 \mathrm{~mm}$ long. Augite is intact and sub-automorph and its diameter reaches up to $6 \mathrm{~mm}$ and contains 5 to 7 percent of rock volume. Spinel (picotite) is observed in some samples by 1 to 3 percent. Serpentine mineral, in some samples, consists 90 percent of the rock volume and is the alteration product of olivine and orthopyroxene. Serpentine has sporadically filled the olivine and enstatite fractures or makes up some parts of rock in fiber and independent form. Carbonate presents in very low contents in some of these rocks. Lherzolite has the less volume than the harzburgite. Lherzolites along with harzburgites are located in the lower part of the ophiolitic complex. They differ from harzburgites in having more than 5 percent clinopyroxene. These rocks have the massive and granular structure. Their color is dark and they contain olivine and orthopyroxene crystals (bronzite) in bronze color. These rocks are somewhat soapy in touch, which indicates the serpentinization of olivine and orthopyroxenes. They have coarse-grain texture and the rock minerals include olivine, enstatite, augite and brown chromite. These rocks contain 5 to 7 percent augite. Olivine presents in the rock by 51 to 60 percentand is sub-automorph and long up to $5 \mathrm{~mm}$ in diameter. The alteration of olivine to serpentine is occurred in some samples up to 50 percent. Orthopyroxene is of enstatite type with a diameter of $8 \mathrm{~mm}$ and is sub-automorph, and contains 14 to 18 percent of the rock volume and sometimes has completely altered into serpentine. Clinopyroxene is of augite type and has made up 5to 7 percent of the rock volume. There are two types of serpentine in the rock. One of them is chrysotile, which is an alteration product of olivine and could be observed in olivine fractures [7] and the other is bastite, which resulted from breakdown of the orthopyroxenes. The mineral has comprised 18 to 23 percent of the rock volume. The opaque mineral is of chromite type and has made up 1 to 5 percent of rock volume. A large part of rocks of the lower part in the ophiolitic complex have been altered through serpentinization and have become serpentinite. Some serpentinites are foliated due to intense pressures. In both fresh and weathered surface, the rock is soapy in touch and tectonic action caused forming smooth and groove surface in the rock. Generally, the original texture in these rocks, which was a medium or coarse-grained or porphyritic texture, has still remained. Sieve texture also presents in some samples. In addition to serpentine, chrome-bearing spinel 
(picotite), magnetite and more or less talc also exist in these rocks. Serpentines are of chrysotile type and antigorite and sometimes bastite. These minerals are alteration product of olivine and orthopyroxene. Sometimes the chromite mineral makes up 1 to 4 percent of the rock volume. Magnetite has secondarily been resulted from decomposition of olivines. Dolerite dykes have formed the thickest portion of the ophiolitic complex, which exposed between Aliabad and Talkhestan villages (Figure 4(a)) and in the northern Darehkhalil village. Their color differs from green to dark gray. They have dense texture. They have intercertal, intergranular, sub-ophitic (Figure 5(d)) and microlitic structure. The minerals of rock include plagioclase, augite, magnetite and sometimes serpentinized olivine. Chlorite and zeolite are the secondary minerals and have been formed as a result of hydrothermal alteration. Pla gioclase is sub-automorph and has comprised up to 52 percent of the rock volume. The length of this mineral is up to 4 $\mathrm{mm}$. Magnetite containing up to 2 percent of the rock volume, is often xenomorph and sometimes automorph. Chlorite could be observed among other minerals. Chlorite, zeolite, zoisite, biotite and sphene (titanite) have secondarily been formed in these rocks. Basaltic lavas were observed in the upper part of the ophiolitic complex with high spreading. There are various outcrops with vast spreading around Akbar Abad (Figure 4(b)) and Khanegha Olyaregions. These basalts have been poured into the water and minerals termolite actinolite, albite, sphene, epidote, chlorite, zeolite and calcite have secondarily been formed as a result of metasomatism and hydrothermal alteration. Olivine contains small percentage of the rock volume and is altered into serpentine. Plagioclases are automorph to sub-automorph the crystals length reaches $1 \mathrm{~mm}$, and are of albite type. Some plagioclases have partially saussuritized. Augite and magnetite also observed in this rock. Pyroxene is of augite type and sub-automorph and dimensions of this mineral reach $5 \mathrm{~mm}$ long and comprises 45 percent of the rock volume. In some samples, the hornblende presents which has become to chlorite due to hydrothermal alteration. This mineral is xenomorph and could be seen amidst plagioclases (Figure 5(h)). Radiolarian cherts of the studied area are exposed in the East of Seyed Khani (Garmab) village in red, brown and black colors. These rocks have not significant extension and have scarce outcrops.

These minerals are hard and dense, but abundant fractures and joints are occurred in them due to tectonic movements. These joints and fractures are secondarily filled by milky quartz and carbonate. Radiolarian cherts are in the upper part of this ophiolite sequence. The presence of these rocks indicates their formation in a deep marine environment, because the original silica shell was dissolved due to pass through the silica compensation depth and secondarily filled by quartz. Accordingly, the presence of the radiolarite fossil in radiolarian cherts suggests that these rocks were deposited in a deep marine environment along with volcanic activities. The reported fossils from the radiolarian cherts propose in the Late Cretaceous age (Mesozoic) for this complex which, in fact, is the same age of the ophiolites emplacement.

\section{Conclusion}

Zagros orogenic belt is as a part of the Alpine orogenic belt across the mountains rang- 

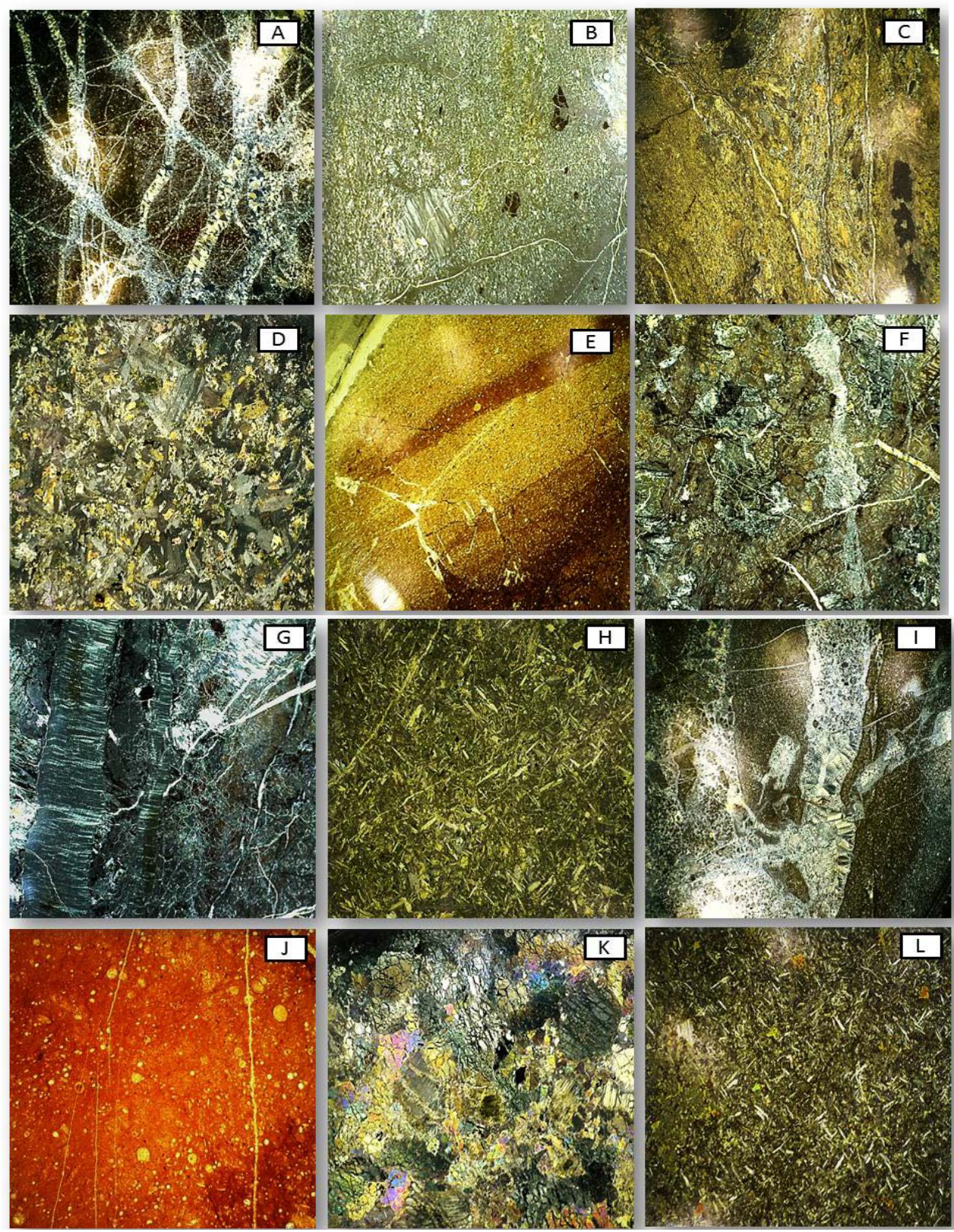

Figure 5. The microscopic images of the ophiolitic complex. (A) Chert with cryptocrystalline texture, polarized light with magnification 40 XPL. (B) Amorphous crystals of chrome-spinel in the harzburgites of northeaster Cheshmeh Golamvais with magnification 40 XPL. (C) Microscopic thin section of serpentinites of the eastern kare pouyanvillage with magnification 40 XPL. (D) Microscopic thin section of dolerites with sub-ophitic texture and magnification 40 XPL. (E) Cherts of the garmab region with cryptocrystalline texture and magnification 40 XPL. (F) Serpentinisedperidotites with cataclastictexture and magnification 40 XPL. (G) Schlieren texture in the serpentinitesof Seyedkhani region with magnification 40 XPL. (H) Sub-ophitic texturewith plagioclase microlites, chlorites resulted from breakdown of pyroxeneand opaque mineral with magnification 40 XPL. (I) Cherts with fibrous(radial) texture and magnification 40 XPL. (J) Ferrous radiolarian chertsof akbar abad area with magnification 40 XPL. (K) Mesh texture of the serpentinizedperidotites with magnification 40 XPL. (L) Basaltic lavaswith intercertal associated with calcite, epidote, plagioclase and augitewith magnification 40 XPL. 
ing from Europe to the Himalayas in Iran that in fact, is the result of compression of the Neotethys syncline in this part of the earth. The study area is located high in the High Zagros Zone. Petrographic study of Mianrahan'sophiolitic complex is started from the ultramafic sequence and followed by sedimentary rocks. Ophiolite sequence of the investigated area is mainly of ultramafic and mafic sequence. The mafic sequence includes the most part of lithology in the area. In this study, 57 samples of rocks of the ophiolitic complex were examined in terms of microscopy. Ultramafic sequence, after mafic series, has the most outcrops and mainly contains harzburgite composition. Lherzolites has not significant extension. The beautiful peridotite outcrop presents in the northeast of Cheshmeh Golamvais. This sequence contains harzburgites (with the most abundance) and lherzolites (with low abundance). The presence of limestones with the Cretaceous age as high altitudes in the studied area suggests that this complex is a part of the Neotethys oceanic crust that has been formed within an extension center in the Late Cretaceous. In the studied area, we have a complete series of a typic oceanic crust.

\section{References}

[1] Stocklin, J. (1968) Structural History and Tectonics of Iran. A Review. AAPG Bulletin, 52, 1229-1258.

[2] Aghanabati, A. (2004) Geology of Iran. Ministry of Industry and Mines, Geological Survey of Iran, Tehran.

[3] Rafia, R. and Shahidi, A. (1999) Geological Map of Sheet Mianrahan, Scale 1:100,000 Geological Survey of Iran, Tehran.

[4] Arian, M.A. and Moienvaziri, H. (1998) Study of Petrography, Petrology and Geochemistry of Igneous Masses Snqr-Axis of Marivan. Thesis, Islamic Azad University, Tehran.

[5] Streckeisen, A. (1979) Classification and Nomenclature of Volcanic Rocks, Lamprophyres, Carbonatites, and Melilitic Rocks: Recommendation and Suggestion of the IUGS, Subcommission on the Systematic of Igneous Rock. Geology, 4, 331-335.

[6] Arian, M.A. and Moienvaziri, H. (1999) Petrography, Stratigraphy and Geochemistry of Kermanshah Ophiolite Complex. 3 rd Symposium of Geological Society, Shiraz, 41-45.

[7] Kerr, P.F. (1990) Optical Mineralogy. 2nd Edition, Tehran University Press, Tehran. 
Submit or recommend next manuscript to SCIRP and we will provide best service for you:

Accepting pre-submission inquiries through Email, Facebook, LinkedIn, Twitter, etc. A wide selection of journals (inclusive of 9 subjects, more than 200 journals)

Providing 24-hour high-quality service

User-friendly online submission system

Fair and swift peer-review system

Efficient typesetting and proofreading procedure

Display of the result of downloads and visits, as well as the number of cited articles

Maximum dissemination of your research work

Submit your manuscript at: http://papersubmission.scirp.org/

Or contact ojms@scirp.org 